- 研究报告・

\title{
西双版纳热带森林附生维管植物的 物种多样性与区系特征
}

\author{
吴 毅 1,2 宋 亮 ${ }^{1}$ 刘 强, 赵明旭 $^{4}$ 卢华正 ${ }^{1,2}$ 谭运洪 $^{5}$ 刘文耀 $^{{ }^{*}}$ \\ 1 (中国科学院西双版纳热带植物园热带森林生态学重点实验室, 云南预腊 666303) \\ 2 (中国科学院大学, 北京 100049) \\ 3 (中国科学院西双版纳热带植物园综合保护中心, 云南预腊 666303) \\ 4 (国家林业局昆明勘察设计院，昆明 650216) \\ 5 (中国科学院西双版纳热带植物园标本与种质保存中心, 云南预腊 666303)
}

\begin{abstract}
摘要: 附生植物是山地森林生态系统中重要的结构性成分。因受林冠调查技术限制, 人们对林冠附生植物知之甚 少。本文在前人有关西双版纳植物区系研究的基础上, 结合野外调查和标本资料, 对该地区附生植物的物种组成 与分布进行了整理。结果表明, 西双版纳热带森林附生维管植物共有 29 科 134 属 486 种, 约占全部维管植物的 $11 \%$ 。 附生兰科是最丰富的类群(69属293种), 其中以石斛属(Dendrobium) (49种)和石豆兰属(Bulbophyllum) (48种)物种数

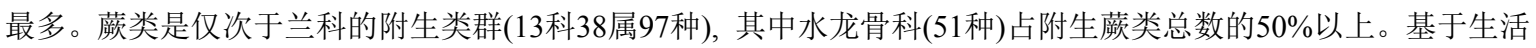
史和养分来源的划分标准，该地区 $48 \%$ 的附生物种属于兼性附生，其次是以兰科为主的专性附生(46\%), 半附生仅 占 $6 \%$ 。从区系上看，西双版纳附生植物属的分布具有明显的热带亚洲性质。附生植物主要分布于资源受限的林冠 生境, 对环境变化极为敏感, 在人为干扰日益加剧的背景下, 这类植物正面临严重威胁。因此, 需要加强对西双版 纳林冠亚系统的保护。
\end{abstract}

关键词: 附生维管植物; 专性附生; 半附生; 兼性附生; 兰科; 水龙骨科; 林冠

\section{Diversity and floristic characteristics of vascular epiphytes in the tropical forest of Xishuangbanna}

\author{
Yi Wu ${ }^{1,2}$, Liang Song ${ }^{1}$, Qiang Liu ${ }^{2,3}$, Mingxu Zhao ${ }^{4}$, Huazheng $\mathrm{Lu}^{1,2}$, Yunhong Tan ${ }^{5}$, Wenyao Liu ${ }^{1 *}$ \\ 1 Key Laboratory of Tropical Forest Ecology, Xishuangbanna Tropical Botanical Garden, Chinese Academy of Sciences, \\ Mengla, Yunnan 666303 \\ 2 University of Chinese Academy of Sciences, Beijing 100049 \\ 3 Center for Integrative Conservation, Xishuangbanna Tropical Botanical Garden, Chinese Academy of Sciences, \\ Mengla, Yunnan 666303 \\ 4 China Forest Exploration \& Design Institute in Kunming, Kunming 650216 \\ 5 Herbarium and Germplasm Conservation Center, Xishuangbanna Tropical Botanical Garden, Chinese Academy of \\ Sciences, Mengla, Yunnan 666303
}

\begin{abstract}
Epiphytes are important structural components of mountain forest ecosystems; however, they have been given insufficient attention because of accessibility issues. In this study, we analyzed the species composition and floristic characteristics of vascular epiphytes in Xishuangbanna using field observations and herbarium specimens, combined with literature records. In total, 486 species (29 families, 134 genera) of vascular epiphytes were identified, contributing to $c a$. $11 \%$ to the Xishuangbanna's vascular flora. Epiphytic orchids were the most abundant taxa (293 species, 69 genera), dominated by Dendrobium (49 species) and Bulbophyllum (48 species). Epiphytic ferns were the second most abundant taxa (13 families, 38 genera, 97 species), with more than half belonging to Polypodiaceae. Obligate, facultative and hemi-epiphytes accounted for $46 \%, 48 \%$, and $6 \%$ of the species, respectively. Epiphytic orchids were the dominant taxa of ob-
\end{abstract}


ligate epiphytes. Analysis of floristic characteristics at the genus level revealed that epiphytic flora in Xishuangbanna belonged to Tropical Southeast Asia. Without access to soil, epiphytes must explore heterogeneous microhabitat in the forest canopy and are sensitive to environmental changes. They are seriously threatened by anthropogenic disturbances. Therefore, conservation for canopy sub-systems is an urgent and practical need in Xishuangbanna.

Key words: vascular epiphytes; obligate epiphyte; hemi-epiphyte; facultative epiphyte; Orchidaceae; Polypodiaceae; canopy

林冠是指森林地表以上全部树冠的集合，包括 所有的叶片、枝条、小枝及附生植物(Nadkarni et al, 1996)。其中，附生植物是一类依赖乔木宿主作为结 构性支撑的非寄生植物(Zotz，2013b)。作为热带山 地森林生态系统中物种数最为丰富的生物类群, 它 们在生态系统水分平衡、养分循环以及为林冠动物 提供食物和庇护场所等方面发挥着关键作用 (Bartels \& Chen, 2012)。这类植物的水分和养分主要 从空气中获取, 对环境变化极为敏感, 可作为监测 气候变化的潜在生物指示种(bio-indicator) (宋亮和 刘文耀, 2011; Leao et al, 2014)。大部分附生植物被 列入《濒危野生动植物物种国际贸易公约》(CITES) 的保护范围, 成为保护生物学的研究热点之一 (Benzing, 2012; Lowman et al, 2013)。

附生植物分为附生非维管植物(地衣、苔藓等) 和附生维管植物 (葓类和种子植物) 两大类群 (Benzing, 2012), 其研究可追溯至1888年Schimper 发表的新热带附生植物专著(Zotz, 2013b)。Madison (1977)在此基础上，首次汇编了全世界65科850属 28,200种附生植物, 后又经Kress (1986)、Gentry和 Dodson (1987)修订, 直到Zotz (2013b) 对附生植物 的定义进行重新界定, 最后确定的附生植物有 73 科 913属27,614种，约占全世界维管植物的 9\%。当前, 附生植物研究多集中在美洲新热带植物区 (Cascante-Marín \& Nivia-Ruíz, 2013), 旧热带植物 区仅有一例关于热带-亚热带过渡岛屿(台湾)附生 植物多样性的研究(Hsu \& Wolf, 2009)。近年来我国 学者对云南哀牢山亚热带湿性常绿阔叶林(Song et al, 2011, 2015a; Li et al, 2015)和海南岛不同热带森 林类型(刘广福等, 2010a, b) 的附生植物多样性与分 布格局进行了一系列较为深入的调查研究。但这些 研究都是基于几个林分的样方调查数据, 区域尺度 的附生植物多样性格局尚未见报道。

西双版纳属于中国陆地生物多样性保护的关
键地区(Tang et al, 2006), 位于全球 25 个生物多样性 热点地区之一的Indo-Burma内(Myers et al, 2000)。 一些学者对该地区的兰科植物多样性与分布进行 了调查(高江云等, 2013; Liu et al, 2015)。Zhang等 (2015b)认为西双版纳是我国附生兰科植物物种丰 富度最高的地区。Zhao等(2015)对该区域布龙自然 保护区的附生维管植物多样性的研究得到了相似 的结论。但与新热带附生植物热点地区相比 (Obermuller et al, 2014), 西双版纳热带森林附生植 物的物种组成、多样性与区系分布仍不清楚。

本文系统整理了西双版纳植物区系中有关附 生植物的研究资料, 旨在确定该地区附生植物科属 组成与物种丰富度, 并分析附生植物的生活型与区 系组成。在此基础上，探讨西双版纳热带森林附生 植物组成与多样性分布特征, 进而为该地区附生植 物多样性的保护与管理提供科学依据。

\section{1 方法}

\section{1 研究地概况}

西双版纳地区总面积 $19,690 \mathrm{~km}^{2}$, 年均温 21.7 ${ }^{\circ} \mathrm{C}$, 年降水量 $1,560 \mathrm{~mm}$, 降水时空分配不均。该地 区的热带森林是水分、热量和海拔极限条件下的热 带北缘森林类型(Zhang et al, 2014), 可分为热带雨 林、热带季节性湿润林、热带季雨林和热带山地常 绿阔叶林 4 个主要的植被型, 共包括 32 个典型群系 (Zhu, 2006; Zhu et al, 2006; 朱华，2007; 朱华等， 2015)。由于地处古热带植物区系向泛北极植物区系 的过渡区和东亚植物区系向喜马拉雅植物区系的 过渡区，西双版纳生物区系成分复杂，物种多样性 高。该地区野生种子植物有 188 科 1,242 属4,152种(朱 华和闵丽春, 2012)。

\section{2 附生植物生活型与附生系数}

本文采用Hsu和Wolf (2009)、Zotz (2013b)的分 类方法, 将附生植物划分为专性附生(obligate epi- 
phyte)、半附生(hemi-epiphyte)和兼性附生(facultative epiphyte) 3 种类型。其中, 专性附生是指不从土 壤基质中完成生活史, 其养分需求来自空气、降水 或宿主植物淋溶; 半附生是指像专性附生一样在宿 主上萌发, 然后其根系下垂延伸至地面土壤; 兼性 附生是除了能在树干基质上生长之外, 在非树木基 质上也能萌发并繁殖。

本文采用Nadkami等(2001)对附生系数(Epiphytic quotient/index)的定义, 即一定地理范围内以附 生形式存在的植物物种数占总物种数的比例。

某一地区的附生系数=附生维管植物物种数/维 管植物总种数 $\times 100 \%$

\section{3 附生植物科属名称和区系划分}

附生植物名录主要从李延辉(1996)、朱华和问 丽春(2012)等西双版纳植物区系专著中逐一篮选。 这两本植物区系专著时间跨度从1957年(首次地区 植物多样性编目)至2012年(最新的整理与修订), 地 理范围涵盖了该地区7 7 主要的植被型及 32 个较为 典型的群系, 覆盖了几乎所有植被类型。这些植物 区系数据是基于植物标本和同行评议文献为依据 的完整植物多样性编目。在此基础上, 我们还参考 了高江云等(2013)和Liu等(2015)关于附生兰科植物 的最新数据以及Liao等(2009)和李剑武等(2015)发 表的新记录物种文献, 并结合作者最近两年的野外 调查、标本馆记录以及植物园各专类园内引种保存 的植物, 依据Zotz (2013b)重新修订的附生植物系 统分布进行整理。只要该地区维管植物中符合Zotz (2013a, b) 界定的专性附生、半附生和兼性附生3种 特征中的任何一种, 即将其视为附生植物。䓲类植 物和种子植物物种学名均依据 Flora of China (http://www.efloras.org/flora_page.aspx?flora_id=2) 逐一核实校对。依据吴征捡等(2010)种子植物属的 分布区类型, 参照陆树刚(2007)关于薮类植物区系 划分方法, 对西双版纳附生植物的科、属区系进行 界定。

\section{2 结果}

\section{1 附生植物科属组成与物种丰富度}

西双版纳热带森林附生植物共有29科134属 486 种 (附录 1 ), 附生系数达 $11 \%$ 。有 12 科含有 5 种以 上的附生植物, 共占全部附生物种数的 $95 \%$ (图1)。 兰科附生物种最为丰富(69属293种), 占全部附生物
种数的 $60 \%$ 。偋类 13 科 38 属 97 种, 占 $20 \%$, 其中水龙 骨科(16属51种)占附生蒴类的半数以上。除兰科之 外的其他种子植物共 15 科 27 属 96 种, 其中含 10 种以 上的有桑科(21种)、苦苣苔科(19种)、萝藦科(16种) 和天南星科(14种), 是本地区附生种子植物的主体。

附生植物大部分集中在少数几个属。有 12 个属 含有 10 个以上的物种，占全部附生物种数的 $47 \%$ (图2); 相反, 有半数的属只有 1 种附生植物。兰科中 的石斛属(Dendrobium, 49种)和石豆兰属(Bulbophyllum, 48种) 附生植物种数最多, 其次是忽尾兰属 (Oberonia, 17种)。蕨类中的铁角偋属(Asplenium)、 瓦韦属(Lepisorus)和石韦属(Pyrrosia)都具有较多的 附生种。桑科榕属(Ficus, 21种)、苦菅苔科芒毛菅 苔属(Aeschynanthus, 15种)和萝藦科球兰属(Hoya,

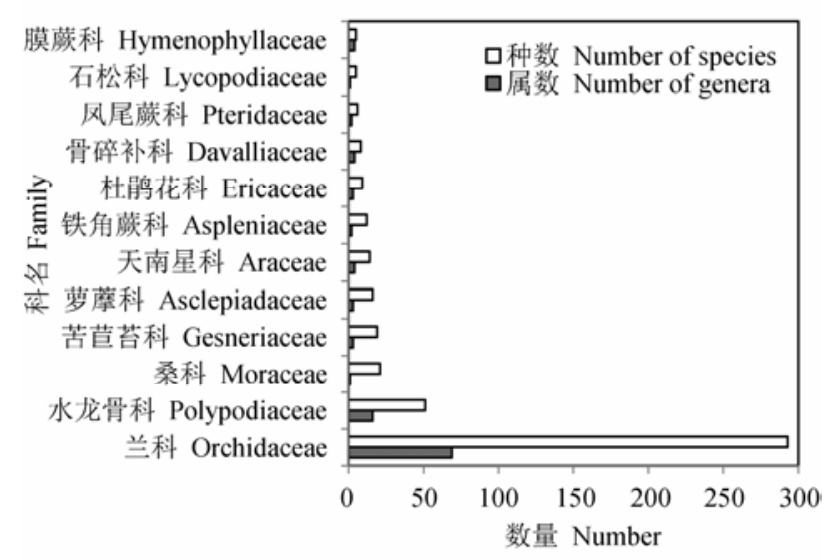

图1 西双版纳具有 5 种以上的附生维管植物科及其属、种数 Fig. 1 Family of vascular epiphytes with more than 5 species of Xishuangbanna and numbers of their genera and species

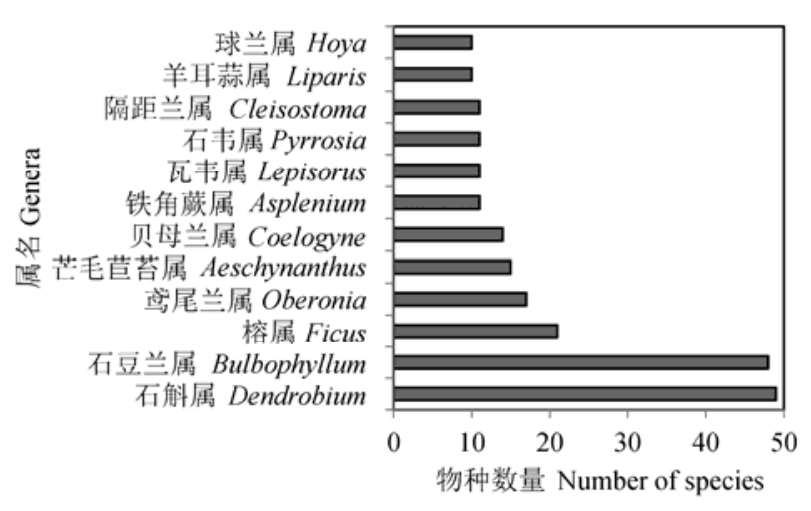

图2 西双版纳具有10种以上的附生植物属及其物种数

Fig. 2 Genera of vascular epiphytes with more than 10 species of Xishuangbanna and number of their species 
10 种)所含附生种数占兰科以外其他附生种子植物 种数的 $48 \%$ 。

\section{2 附生植物生活型}

附生植物的 $48 \%$ 是兼性附生(233种), 但生长在 地面的兼性附生物种很少, 只有 10 种, 绝大部分是 附生-石生类型(223种)。完全以树干为基质的专性 附生有 223 种, 比兼性附生略少。而半附生只有 30 种, 仅占 $6 \%$ 。

从物种组成来看, 兼性附生大部分由兰科和䓲 类组成, 其中兰科 112 种, 蕨类 80 种, 二者占兼性附 生的 $82 \%$ 。兼性附生的其他种子植物有苦菅苔科 $(8$ 种)、天南星科(5种)以及杜鹃花科(4种)等。专性附 生中主要是兰科(181种), 其次是苦苣苔科(11种)和 萝藦科(10种), 蕨类只有13种。桑科榕属以绞杀方式 形成半附生生活型(图3)。值得注意的是, 天南星科 中既有专性附生, 如预海南星(Arisaema lackneri);
又有半附生，如崖角藤属(Rhaphidophora); 也有兼 性附生, 如石柑属(Pothos)和岩芋属(Remusatia)。

\section{3 附生植物属的分布区类型}

西双版纳附生植物的 96 个种子植物属和 38 个 䓲类植物属的分布区类型如下 (表1)：热带分布属 (类型2-7)共计 118 个, 占总属数的 $88 \%$ 。其中, 热带 亚洲分布属最多, 共计 45 个, 占总属数的 $33.6 \%$, 如 球兰属、芒毛苣苔属、树萝卜属(Agapetes)、盆距兰 属(Gastrochilus)、指甲兰属(Aerides)和薄唇偋属 (Leptochilus)等。其次是热带亚洲至热带大洋洲分布 属, 共计 30 个, 占总属数的 $22.4 \%$, 如眼树莲属 (Dischidia)、兰属(Cymbidium)、石斛属、槲偋属 (Drynaria) 和拟水龙骨属(Polypodiastrum) 等。泛热 带分布属共有 14 个, 占总属数的 $10.5 \%$, 位居第三, 如石豆兰属、榕属、草胡椒属(Peperomia)、我掌柴 属(Schefflera)、书带硕属(Haplopteris) 等。非热带分

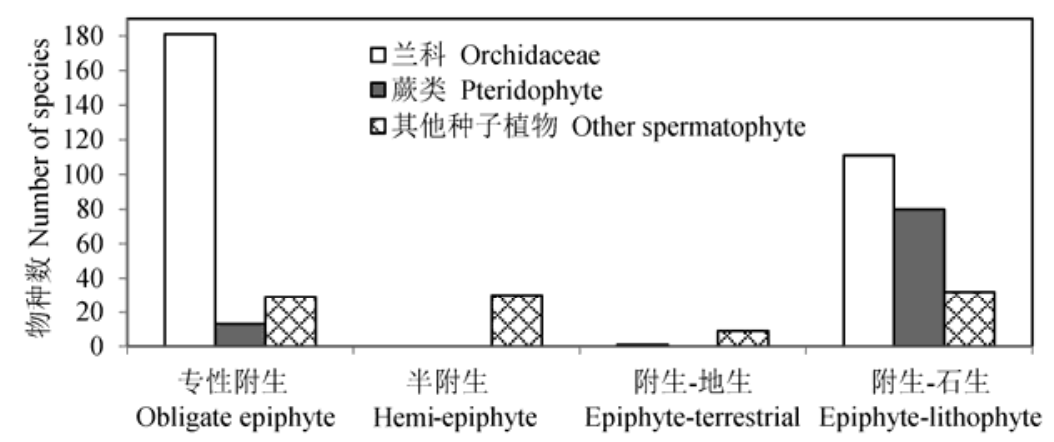

图3 西双版纳不同附生生活型的维管植物物种数

Fig. 3 Number of species of vascular epiphytes with different sub-categories of Xishuangbanna

\section{表1 西双版纳附生维管植物属的分布区类型}

Table 1 Areal types of genera for vascular epiphytes from Xishuangbanna

\begin{tabular}{|c|c|c|c|c|}
\hline \multirow{2}{*}{$\begin{array}{l}\text { 分布区类型 } \\
\text { Areal types }\end{array}$} & \multicolumn{2}{|c|}{ 种子植物 Seed plants } & \multicolumn{2}{|c|}{ 蕨类植物 Pteridophytes } \\
\hline & $\begin{array}{l}\text { 属数 Number of } \\
\text { genera }\end{array}$ & $\begin{array}{l}\text { 比例 Propor- } \\
\text { tion }(\%)\end{array}$ & $\begin{array}{l}\text { 属数 Number of } \\
\text { genera }\end{array}$ & $\begin{array}{l}\text { 比例 Proportion } \\
(\%)\end{array}$ \\
\hline 1. 世界分布 Cosmopolitan & 2 & 1.49 & 7 & 5.22 \\
\hline 2. 泛热带分布 Pantropic & 5 & 3.73 & 9 & 6.72 \\
\hline 4. 旧世界热带分布 Old World Tropic & 6 & 4.48 & 4 & 2.99 \\
\hline $\begin{array}{l}\text { 5. 热带亚洲至热带大洋洲分布 Tropical Asia to Tropical Austral- } \\
\text { asia Oceania }\end{array}$ & 27 & 20.15 & 3 & 2.24 \\
\hline 6. 热带亚洲至热带非洲分布 Tropical Asia to Tropical Africa & 4 & 2.99 & 6 & 4.48 \\
\hline $\begin{array}{l}\text { 7. 热带亚洲分布 Tropical Southeast Asia to Indo-Malaya \& Tropi- } \\
\text { cal Southwest Pacific Islands }\end{array}$ & 41 & 30.60 & 4 & 2.99 \\
\hline 2-7热带成分合计 2-7 Subtotal Tropical elements & 85 & 63.43 & 33 & 24.63 \\
\hline 8. 北温带分布 North Temperate & 3 & 2.24 & - & - \\
\hline 14. 东亚分布 East Asia & 8 & 5.97 & 5 & 3.73 \\
\hline 合计 Total (134) & 96 & 71.64 & 38 & 28.36 \\
\hline
\end{tabular}


布属共 16 个, 占总属数的 $11.9 \%$, 位于东亚分布及 北温带分布, 如越桔属(Vaccinium)、吊石苣苔属 (Lysionotus)、槽舌兰属(Holcoglossum)、伏石葓属 (Lemmaphyllum)、水龙骨属(Polypodiodes)等。

\section{3 讨论}

\section{1 附生植物科属组成与物种丰富度}

附生植物的系统分布对于研究该类群的生态 适应性与进化具有重要意义(Zotz, 2013b)。兰科是 被子植物中最丰富的类群, $70 \%$ 以上的物种栖息在 林冠层(Gravendeel et al, 2004)。兰科辐射进化主要 与其花粉块构造、附生生境、景天酸代谢以及昆虫 传粉有关(Givnish et al, 2015)。其中, 石豆兰属在东 南亚热带林冠中物种最为丰富 (Schuiteman \& de Vogel, 2007)。薄囊蒴类经历了新生代第四次快速分 化, 使之能够在被子植物主导的热带森林中占据林 冠生态位, 以进化类群如水龙骨科和骨碎补科为代 表(张宪春, 2012)。西双版纳的兰科附生物种最为丰 富, 其中石斛属和石豆兰属附生种数最多; 其次是 硕类, 其中水龙骨科占附生蒝类半数以上。这种科 属组成和物种丰富度在一定程度上体现了兰科和 颜类植物对附生生活型的适应性进化。

西双版纳是植物多样性的热点地区，尽管其面 积仅占中国陆域国土面积的 $0.2 \%$, 却承载了 $16 \%$ 的 高等植物种类(Zhang \& Cao, 1995)。该地区附生植 物共有 29 科 134 属 486 种, 附生系数达 $11 \%$, 高于世 界平均水平 $(9 \%)$ (Zotz, 2013b), 低于新热带附生植 物多样性热点地区 (5.2-27.7\%, 平均为 $17.5 \%)$ (Cascante-Marín \& Nivia-Ruíz, 2013)。分析表明, 造 成该区附生植物物种丰富的原因主要有以下 4 个方 面: (1)对附生植物而言, 雾的水分可用性能超过垂 直降水(Song et al, 2015b)。尽管西双版纳位于具有 季节性干旱的热带北缘, 但却是我国辐射雾雾日 多、雾时长、雾量大的典型区域(黄玉生等, 2000), 这 在一定程度上弥补了干季的降雨不足(Liu et al, 2014)。(2)尽管已有研究表明频繁的风具风易对附生 植物种群产生干扰, 能将之从宿主上剥离, 从而降 低附生物种多样性(如在波多黎各和中国台湾) (Hsu \& Wolf, 2009; Zotz \& Bader, 2009), 但西双版纳是 著名的热带静风区(张一平等, 2000), 风暴造成的干 扰因素较少。(3)西双版纳森林植被丰富多样, 共包 括32个较为典型的群系(朱华等, 2015), 这为附生植
物提供了多样的生境，同时占该地区面积 $19 \%$ 的热 带季节性湿润林也蕴含着丰富的附生物种(Zhu et al, 2003; Zhu, 2006; 朱华, 2007)。(4)历史和社会经 济因素也可能会影响区域植物采集(Yang et al, 2014)。

\section{2 附生植物的生活型}

自 120 多年前Schimper的开创性研究以来, 人 们对附生植物及其生活型的理解尚无统一标准, 至 今仍有争论(Benzing, 1990; Moffett, 2000)。如按生 境中附生种群个体的比例(Zotz, 2005)、按生活史的 某个阶段与地面有无联系(Benzing, 2012)、按基质 类型和养分来源(Benzing, 2004)可分为不同类型的 附生植物。本文综合采用Hsu和Wolf (2009)、Zotz (2013b)的最新分类方法, 考虑附生植物的生活史、 对树皮基质的忠实程度以及养分来源, 结合研究地 区的野外观察, 采取专性附生、半附生和兼性附生 的划分标准。专性附生通常不从附生基质获取矿质 养分(Zotz，2013a)。半附生在生活史期间附生基质 会发生转化, 因此不受基质的约束。兼性附生经常 利用附生基质，这种基质可以是乔木宿主，亦或是 岩石或土壤(Benzing, 2012)。

西双版纳地区 $48 \%$ 的附生物种是兼性附生(233 种), 以兰科和硕类为主。其次是专性附生(223种), 以兰科为主, 䒴类很少; 而半附生仅 30 种, 主要是 桑科榕属和天南星科崖角藤属植物。植物进化为附 生生活型后能获得更多的光照、逃避捕食者并提高 传粉效率，但因失去了与土壤接触的机会而面临更 为频繁的水分和严重的养分胁迫(Benzing, 2012)。 以附生兰为例, 它们可通过增加叶片咜水能力使植 物体内的水分平衡和生理功能在水分胁迫时维持 更长时间, 这是其适应附生生境的重要策略之一 (Zhang et al, 2015a)。对兼性附生而言, 北半球兼性 附生植物最多, 且通常出现在森林地面; 南半球则 以专性附生为主, 多数出现在林冠(Burns, 2010)。此 外, 兼性附生能够规避专性附生生境中的生理和资 源限制, 有效利用林冠和地面的资源, 可在附生生 境维持有效的竞争(Testo \& Sundue, 2014)。这可以 在一定程度上解释为何在西双版纳具有较高比例 的兼性附生植物。对半附生榕属而言, 由于在林冠 萌发, 不需依赖森林中的林窗, 减少了与其他物种 的竞争, 使其成为最大的半附生木本植物类群(Hao et al, 2011)。此外, 半附生榕(如雅榕(Ficus con- 
cinna))幼苗具有更为保守的水分传导和利用方式, 能在更干旱的林冠生境存活(Hao et al, 2013)。

兼性附生中, 绝大部分是附生-石生类型(223 种), 而附生-地生类型很少(10种), 这可能与附生 基质的水分稳定性有关。Benzing (2004)认为, 若林 冠环境向森林地面环境收敛(convergence), 则兼性 附生植物的多样性和多度将会更多。如条件严酷的 干旱生境, 林冠和陆地基质区别不大, 宿主缺乏且 竞争降低时, 附生植物通常会生长在岩石表面 (Johansson, 1974; Zotz, 2005)。这种现象在本研究中 的热带喀斯特森林表现得尤为明显。如水龙骨科槲 䲞属、瓦韦属、石韦属以及兰科的石豆兰属、贝母 兰属(Coelogyne)、石斛属等, 在石灰岩和树干表面 都有分布。这类附生植物一般具有根状茎、假鳞茎、 气生根、肉质叶、表皮毛等旱生构造(Hietz，2010; Kreft et al, 2010)。相反, 在潮湿地点如沟谷雨林的 溪流附近, 树枝/树干和林地土壤都具有厚实保水 的苔藓、地衣以及调落物覆盖时, 陆生植物可能生 长在树上而出现兼性附生(Kelly et al, 1994; Zotz, 2013b), 如狸藻科的圆叶挖耳草(Utricularia striatula) 以及膜硕科的蕗硕(Hymenophyllum badium) 等。 但这类附生植物不具备专门的适应附生生境的结 构, 且分布区有限, 故物种数稀少。

\section{3 西双版纳附生植物区系与其他植物区系的比} 较

西双版纳附生植物共134个属的分布区类型表 明, 热带分布属占总属数的 $88 \%$, 属于热带性质的 植物区系。其中又以热带亚洲分布属比例最大, 占 总属数的 $33.6 \%$, 显示了较强的热带亚洲亲缘。这 与朱华和闰丽春(2012)用种子植物属的分布区得出 整个西双版纳区域种子植物以热带亚洲成分占优 势的结论一致。值得注意的是, 附生种子植物热带 分布属占总属数的 $62 \%$, 比种子植物属热带成分 (77\%)低, 意味着附生硕类的热带分布属具有一定 的贡献。

西双版纳附生兰科 $(60 \%)$ 与附生蕨类 $(20 \%)$ 在 全部附生植物中的占比, 反映了该地区附生植物组 成介于赤道热带和热带-亚热带过渡区中间的热带 北缘性质。不同气候带下附生植物的组成格局已在 一些研究中得到验证, 如位于赤道热带的新加坡, 附生兰科占该地区附生植物的70\% (Chong et al, 2009，2011), 而热带亚热带过渡岛屿中国台湾的附
生兰科仅占 $36 \%$, 相对应的是台湾的附生烣类占全 部附生植物的 $51 \%$ (Hsu \& Wolf 2009)。尽管新热带 墨西哥Chiapas州附生系数高达 $14 \%$, 但附生兰科占 比(48\%)却比西双版纳低。这主要由于新热带分布 有凤梨科、仙人掌科等几个非古热带分布典型科的 大量附生物种，从而降低了附生兰科的比例(Wolf \& Alejandro, 2003)。一般而言, 热带森林中的附生 植物以兰科物种最为丰富(Wester et al, 2011), 其原 因可能是兰科自身以热带分布为主。热带有更广衰 的生境, 稳定的气候, 且与互惠传粉者和专一性草 食动物协同进化，这些因素综合起来使得热带分布 的物种形成速率高于非热带分布种(Givnish et al, 2015); 而温带地区则以蕨类植物占优势，其原因可 能与温带水分可用性低以及气温较低有关(Zotz, 2005)。

\section{4 附生植物面对环境变化的脆弱性}

近半个世纪来, 西双版纳橡胶种植园不断扩 张，原生森林植被面积缩小并呈片断化分布，导致 区域生物多样性下降(Liu \& Slik, 2014; Xu et al, 2014)。如望天树(Parashorea chinensis)林原本位于 保护区的核心位置, 被橡胶林不断蚕食后, 逐渐位 于保护区外围, 群落生境逐渐由凉湿向干暖转变, 导致喜湿耐阴的附生植物减少(梁娟等, 2007; Zhu et al，2010)。此外，因受过度采集和贸易活动的影 响，部分珍稀的具有观赏和药用价值的附生植物如 石斛属、万代兰属 $($ Vand $a$ ) 等野生种群数量急剧减少, 甚至濒临灭绝(高江云等, 2013; Liu et al, 2015)。在 西双版纳附生兰科植物中, 针叶石斛(Dendrobium pseudotenellum)和砚山毛兰(Eria yanshanensis)可能 已野外灭绝(Extinct in the Wild); 10种附生兰是极危 (Critically Endangered), 另外还有 54 种濒危 (Endangered)。若按《中国物种红色名录》(汪松和 解炎, 2004)的濒危等级, 则有 27 种极危、91种濒危 附生兰科植物(Liu et al, 2015)。

林冠附生植物位于森林与大气层相互作用的 关键生态界面, 它们暴露在空气中, 直接吸收空气 中的水分和养分以维持其生命过程, 对环境变化极 为敏感(宋亮和刘文耀，2011; Benzing，2012)，人类 活动导致的干扰和动态过程对附生类群的威胁更 为严重(Leao et al, 2014)。如新加坡热带雨林片断化 100 多年来, 有594种乡土植物已灭绝。在297种附生 植物中，已消失 185 种，占附生总数的 $62 \%$ ，其中， 
196种兰科植物中的173种已消失(Turner et al, 1994, 1996)。在干扰频繁的生态系统中, 附生植物的灭绝 风险更高，属于最脆弱的类群(Sodhi et al，2008; Leao et al, 2014)。因此, 附生植物多样性可以作为 生境健康与否的生物指示类群, 用于评估森林受干 扰程度(Turner et al, 1994)。在今后的生物多样性保护 中, 林冠附生亚系统应作为优先保护目标予以考虑。

\section{参考文献}

Bartels SF, Chen HYH (2012) Mechanisms regulating epiphytic plant diversity. Critical Reviews in Plant Sciences, 31, 391-400.

Benzing DH (1990) Vascular Epiphytes: General Biology and Related Biota. Cambridge University Press, New York.

Benzing DH (2004) Vascular epiphytes. In: Forest Canopies 2nd edn (eds Lowman MD, Rinker HB). Springer Verlag, Berlin.

Benzing DH (2012) Air Plants: Epiphytes and Aerial Gardens. Cornell University Press, London.

Burns KC (2010) How arboreal are epiphytes? A null model for Benzing's classifications. New Zealand Journal of Botany, 48, 185-191.

Cascante-Marín A, Nivia-Ruíz A (2013) Neotropical flowering epiphyte diversity: local composition and geographic affinities. Biodiversity and Conservation, 22, 113-125.

Chong KY, Tan HT, Corlett RT (2009) A Checklist of the Total Vascular Plant Flora of Singapore: Native, Naturalised and Cultivated Species. Raffles Museum of Biodiversity Research, National University of Singapore.

Chong KY, Tan HT, Corlett RT (2011) A summary of the total vascular plant flora of Singapore. Gardens' Bulletin Singapore, 63, 197-204.

Gao JY, Liu Q, Yu, DL (2013) Diversity and Conservation of Orchids in Xishuangbanna. China Forestry Publishing House, Beijing. (in Chinese) [高江云, 刘强, 余东莉 (2013) 西双版纳的兰科植物多样性和保护. 中国林业出 版社, 北京.]

Gentry AH, Dodson CH (1987) Diversity and biogeography of neotropical vascular epiphytes. Annals of the Missouri Botanical Garden, 74, 205-233.

Givnish TJ, Spalink D, Ames M, Lyon SP, Hunter SJ, Zuluaga A, Cameron KM (2015) Orchid phylogenomics and multiple drivers of their extraordinary diversification. Proceedings of the Royal Society B: Biological Sciences, 282, 20151553.

Gravendeel B, Smithson A, Slik FJW, Schuiteman A (2004) Epiphytism and pollinator specialization: drivers for orchid diversity? Philosophical Transactions of the Royal Society of London B: Biological Sciences, 359, 1523-1535.

Hao GY, Wang AY, Sack L, Goldstein G, Cao KF (2013) Is hemiepiphytism an adaptation to high irradiance? Testing seedling responses to light levels and drought in hemiepiphytic and non-hemiepiphytic Ficus. Physiologia Plantarum, $148,74-86$.
Hao GY, Goldstein G, Sack L, Holbrook NM, Liu ZH, Wang AY, Cao KF (2011) Ecology of hemiepiphytism in fig species is based on evolutionary correlation of hydraulics and carbon economy. Ecology, 92, 2117-2130.

Hietz P (2010) Ecology and ecophysiology of epiphytes in tropical montane cloud forests. In: Tropical Montane Cloud Forests Science for Conservation and Management (eds Bruijnzeel LA, Scatena FN, Hamilton LS), pp. 67-76. Cambridge University Press, Cambridge, UK.

Hsu R, Wolf JHD (2009) Diversity and phytogeography of vascular epiphytes in a tropical-subtropical transition island, Taiwan. Flora-Morphology, Distribution, Functional Ecology of Plants, 204, 612-627.

Huang YS, Huang YR, Li ZH, Chen BJ, Huang JP, Gu JX (2000) The microphysical structure and evolution of winter fog in Xishuangbanna. Acta Meteorologica Sinica, 58, 715-725. (in Chinese with English abstract) [黄玉生, 黄玉 仁, 李子华, 陈宝君, 黄建平, 顾江新 (2000) 西双版纳 冬季雾的微物理结构及演变过程. 气象学报, 58 , 715-725.]

Johansson D (1974) Ecology of vascular epiphytes in West African rain forest. Acta Phytogeographica Suecica, 59, $1-139$.

Kelly DL, Tanner EVJ, Lughadha EMN, Kapos V (1994) Floristics and biogeography of a rain-forest in the Venezuelan Andes. Journal of Biogeography, 21, 421-440.

Kreft H, Jetz W, Mutke J, Barthlott W (2010) Contrasting environmental and regional effects on global pteridophyte and seed plant diversity. Ecography, 33, 408-419.

Kress WJ (1986) The systematic distribution of vascular epiphytes: an update. Selbyana, 9, 2-22.

Leao TCC, Fonseca CR, Peres CA, Tabarelli M (2014) Predicting extinction risk of Brazilian atlantic forest angiosperms. Conservation Biology, 28, 1349-1359.

Li JW, Ye DP, Liu JX, Tan YH, Yin JT (2015) Orchids newly recorded to China. Plant Diversity and Resourses. 37, 246-252. (in Chinese with English abstract) [李剑武, 叶德 平, 刘景欣, 谭运洪, 殷建涛 (2015) 中国兰科植物新资 料. 植物分类与资源学报, 37, 246-252.]

Li YH (1996) List of Higher Plant of Xishuangbanna. Yunnan Nationalities Publishing House, Kunming. (in Chinese) [李 延辉 (1996) 西双版纳高等植物名录. 云南民族出版社, 昆明.]

Li S, Liu WY, Li DW, Song L, Shi XM, Lu HZ (2015) Species richness and vertical stratification of epiphytic lichens in subtropical primary and secondary forests in southwest China. Fungal Ecology, 17, 30-40.

Liang J, Zhu H, Wang H, Zhou SS (2007) Changes in species diversity of parashorea forest in the past 20 years in Xishuangbanna, Yunnan. Chinese Journal of Applied and Environmental Biology, 13, 609-614. (in Chinese with English abstract) [梁娟, 朱华, 王洪, 周仕顺 (2007) 西双版 纳补蚌地区望天树林近 20 年来物种多样性变化研究. 应 用与环境生物学报, 13, 609-614.] 
Liao MF, Wang H, Deng YF (2009) Two newly recorded species of Dischidia (Asclepiadaceae) from China. Journal of Tropical and Subtropical Botany, 17, 355-357.

Liu GF, Ding Y, Zang RG, Xu YY, Lin C, Li XC (2010a) Diversity and distribution of vascular epiphytes in the tropical natural coniferous forest of Hainan Island, China. Chinese Journal of Plant Ecology, 34, 1283-1293. (in Chinese with English abstract) [刘广福, 丁易, 藏润国, 许洋瑜, 林崇, 李小成 (2010a) 海南岛热带天然针叶林附生维管植物多 样性和分布. 植物生态学报, 34, 1283-1293.]

Liu GF, Zang RG, Ding Y, Wang WY, Li RC, Chen SW, Zhou ZL (2010b) Diversity and distribution of epiphytic orchids in different types of old-growth tropical forests in Bawangling National Nature Reserve, Hainan Island, China. Chinese Journal of Plant Ecology, 34, 396-408. (in Chinese with English abstract) [刘广福, 蔵润国, 丁易, 王文毅, 李 儒财，陈少伟，周照骊 (2010b) 海南霸王岭不同森林类 型附生兰科植物的多样性和分布. 植物生态学报, 34 , 396-408.]

Liu JJ, Slik JWF (2014) Forest fragment spatial distribution matters for tropical tree conservation. Biological Conservation, 171, 99-106.

Liu Q, Chen J, Corlett R, Fan XL, Yu DL, Yang HP, Gao JY (2015) Orchid conservation in a biodiversity hotspot: status assessment, threats and conservation strategies. Conservation Biology, 29, 1563-1572.

Liu WJ, Li PJ, Duan WP, Liu WY (2014) Dry-season water utilization by trees growing on thin karst soils in a seasonal tropical rainforest of Xishuangbanna, Southwest China. Ecohydrology, 7, 927-935.

Lowman M, Devy S, Ganesh T (2013) Tree Tops at Risk: Challenges of Global Canopy Ecology and Conservation. Springer, New York.

Lu SG (2007) Pteridology. Higher Eduction Press, Beijing. (in Chinese) [陆树刚 (2007) 蕨类植物学. 高等教育出版社, 北京.]

Madison M (1977) Vascular epiphytes: their systematic occurrence and salient features. Selbyana, 2, 1-13.

Moffett MW (2000) What's "Up"? A critical look at the basic terms of canopy biology. Biotropica, 32, 569-596.

Myers N, Mittermeier RA, Mittermeier CG, da Fonseca GA, Kent J (2000) Biodiversity hotspots for conservation priorities. Nature, 403, 853-858.

Nadkami N M, Mewin M C, Niedert J (2001) Forest canopies: plant diversity. In: Encyclopedia of Biodiversity (ed. Levin S), pp. 27-40. Academic Press, San Diego, California.

Nadkarni NM, Parker GG, Ford ED, Cushing JB, Stallman C (1996) The international canopy network: a pathway for interdisciplinary exchange of scientific information on forest canopies. Northwest Science, 70, 104-108.

Obermuller FA, Freitas L, Daly DC, Silveira M (2014) Patterns of diversity and gaps in vascular (hemi-) epiphyte flora of Southwestern Amazonia. Phytotaxa, 166, 259-272.

Schuiteman A, de Vogel EF (2007) Orchidaceae of Papua. Ecology of Indonesian Papua Part One, 435.
Sodhi NS, Koh LP, Peh KSH, Tan HTW, Chazdon RL, Corlett RT, Bradshaw CJA (2008) Correlates of extinction proneness in tropical angiosperms. Diversity and Distributions, $14,1-10$.

Song L, Liu WY (2011) Epiphytic plants: their responses to global change and roles in bioindication. Chinese Journal of Ecology, 30, 145-154. (in Chinese with English abstract) [宋亮, 刘文耀 (2011) 附生植物对全球变化的响应及其 生物指示作用. 生态学杂志, 30, 145-154.]

Song L, Liu WY, Ma WZ, Tan ZH (2011) Bole epiphytic bryophytes on Lithocarpus xylocarpus (Kurz) Markgr. in the Ailao Mountains, SW China. Ecological Research, 26, 351-363.

Song L, Ma WZ, Yao YL, Liu WY, Li S, Chen K, Nakamura A (2015a) Bole bryophyte diversity and distribution patterns along three altitudinal gradients in Yunnan, China. Journal of Vegetation Science, 26, 576-587.

Song L, Zhang YJ, Chen X, Li S, Lu HZ, Wu CS, Shi XM (2015b) Water relations and gas exchange of fan bryophytes and their adaptations to microhabitats in an Asian subtropical montane cloud forest. Journal of Plant Research, 128, 573-584.

Tang Z, Wang Z, Zheng C, Fang J (2006) Biodiversity in China's mountains. Frontiers in Ecology and the Environment, $4,347-352$.

Testo W, Sundue M (2014) Primary hemiepiphytism in Colysis ampla (Polypodiaceae) provides new insight into the evolution of growth habit in ferns. International Journal of Plant Sciences, 175, 526-536.

Turner IM, Chua KS, Ong JSY, Soong BC, Tan HTW (1996) A century of plant species loss from an isolated fragment of lowland tropical rain forest. Conservation Biology, 10, 1229-1244.

Turner IM, Tan HTW, Wee YC, Ibrahim AB, Chew PT, Corlett RT (1994) A study of plant-species-extinction in Singapore: lessons for the conservation of tropical biodiversity. Conservation Biology, 8, 705-712.

Wang S, Xie Y (2004) China Species Red List. Higher Education Press, Beijing. (in Chinese) [汪松, 解炎 (2004) 中国 物种红色名录. 高等教育出版社, 北京.]

Wester S, Mendieta-Leiva G, Nauheimer L, Wanek W, Kreft H, Zotz G (2011) Physiological diversity and biogeography of vascular epiphytes at Río Changuinola, Panama. Flora-Morphology, Distribution, Functional Ecology of Plants, 206, 66-79.

Wolf JHD, Alejandro F (2003) Patterns in species richness and distribution of vascular epiphytes in Chiapas, Mexico. Journal of Biogeography, 30, 1689-1707.

Wu ZY, Sun H, Zhou ZK, Li DZ, Peng H (2010) Floristics of Seed Plants from China. Science Press, Beijing. (in Chinese) [吴征镒, 孙航, 周浙昆, 李德铢, 彭华 (2010) 中国种子 植物区系地理. 科学出版社, 北京.]

Xu JC, Grumbine RE, Beckschäfer P (2014) Landscape transformation through the use of ecological and socioeconomic indicators in Xishuangbanna, Southwest China, Mekong 
Region. Ecological Indicators, 36, 749-756.

Yang WJ, Ma KP, Kreft H (2014) Environmental and socio-economic factors shaping the geography of floristic collections in China. Global Ecology and Biogeography, 23, 1284-1292.

Zhang XC (2012) Lycophytes and Ferns of China. Peking University Press, Beijing. (in Chinese) [张宪春 (2012) 中 国石松类和蕨类植物. 北京大学出版社, 北京.]

Zhang YP, Ma YX, Liu YH, Zhang KY (2000) Horizontal thermal characteristics at forest edge in calm tropical region of China. Chinese Journal of Applied Ecology, 11, 205-209. (in Chinese with English abstract) [张一平, 马友金金, 刘玉 洪, 张克映 (2000) 中国热带静风区林缘水平热力特征 的初步分析. 应用生态学报, 11, 205-209.]

Zhang JH, Cao M (1995) Tropical forest vegetation of Xishuangbanna, SW China and its secondary changes, with special reference to some problems in local nature conservation. Biological Conservation, 73, 229-238.

Zhang SB, Dai Y, Hao GY, Li JW, Fu XW, Zhang JL (2015a) Differentiation of water-related traits in terrestrial and epiphytic Cymbidium species. Frontiers in Plant Science, 6, 260.

Zhang YJ, Holbrook NM, Cao KF (2014) Seasonal dynamics in photosynthesis of woody plants at the northern limit of Asian tropics: potential role of fog in maintaining tropical rainforests and agriculture in Southwest China. Tree Physiology, 34, 1069-1078.

Zhang Z, Yan Y, Tian Y, Li J, He JS, Tang Z (2015b) Distribution and conservation of orchid species richness in China. Biological Conservation, 181, 64-72.

Zhao MX, Nalaka G, Rhett HD, Xu JC, Myo KM, Dian RN, Ekananda P (2015) Diversity and vertical distribution of vascular epiphytes in Bulong Nature Reserve Mengsong Section, Xishuangbanna. Plant Diversity and Resources, 37, 327-338.

Zhu H, Yan LC (2012) Native Seed Plants in Xishuangbana of
Yunnan. Science Press, Beijing. (in Chinese) [朱华, 问丽春 (2012) 云南西双版纳野生种子植物. 科学出版社, 北京.]

Zhu H (2007) On the classification of forest vegetation in Xishuangbanna, Southern Yunnan. Acta Botanica Yunnanica, 29, 377-387. (in Chinese with English abstract) [朱 华 (2007) 论滇南西双版纳的森林植被分类. 云南植物 研究, 29, 377-387.]

Zhu H, Wang H, Li BG, Zhou SS, Zhang JH (2015) Studies on the forest vegetation of Xishuangbanna. Plant Science Journal, 33, 641-726. (in Chinese with English abstract) [朱华, 王洪, 李保贵, 周仕顺, 张建侯 (2015) 西双版纳森林植 被研究. 植物科学学报, 33, 641-726.]

Zhu H (2006) Forest Vegetation of Xishuangbanna, South China. Forestry Studies in China, 8(2), 1-58.

Zhu H, Cao M, Hu HB (2006) Geological history, flora, and vegetation of Xishuangbanna, southern Yunnan, China. Biotropica, 38, 310-317.

Zhu H, Wang H, Baogui L, Sirirugsa P (2003) Biogeography and floristic affinities of the limestone flora in southern Yunnan, China. Annals of the Missouri Botanical Garden, 90, 444-465.

Zhu H, Wang H, Zhou SS (2010) Species diversity, floristic composition and physiognomy changes in a rainforest remnant in southern Yunnan, China after 48 years. Journal of Tropical Forest Science, 22, 49-66.

Zotz G (2005) Vascular epiphytes in the temperate zones: a review. Plant Ecology, 176, 173-183.

Zotz G (2013a) 'Hemiepiphyte': a confusing term and its history. Annals of Botany, 111, 1015-1020.

Zotz G (2013b) The systematic distribution of vascular epiphytes: a critical update. Botanical Journal of the Linnean Society, 171, 453-481.

Zotz G, Bader M (2009) Epiphytic Plants in a Changing World: Global Change Effects on Vascular and Non-Vascular Epiphytes. Progress in Botany, 70, 147-170.

(责任编委: 歲润国 责任编辑: 黄祥忠)

\section{附录 Supplementary Material}

\section{附录1 西双版纳附生维管植物名录}

Appendix 1 The checklist of vascular epiphytes of Xishuangbanna http:// www.biodiversity-science.net/fileup/PDF/2015308-1.pdf 
吴毅, 宋亮, 刘强, 赵明旭, 卢华正, 谭运洪, 刘文耀. 西双版纳热带森林附生维管植物的物种多样性与区系特征. 生物多样性, 2016, 24（3）：271-279.

http://www. biodiversity-science. net/CN/10. 17520/biods. 2015308

\section{附录 1 西双版纳附生维管植物名录}

Appendix 1 The Checklist of vascular epiphytes of Xishuangbanna

\begin{tabular}{|c|c|c|c|}
\hline 科 Family & 属 Genera & 种 Species & $\begin{array}{l}\text { 生活型 } \\
\text { Life form }\end{array}$ \\
\hline \multirow[t]{5}{*}{ 石松科 Lycopodiaceae } & 马尾杉属 Phlegmariurus & 华南马尾杉 P. austrosinicus & 附生-石生 \\
\hline & & 福氏马尾杉 P. fordii & 附生-石生 \\
\hline & & 椭圆叶马尾杉 P. henryi & 附生 \\
\hline & & 马尾杉 P. phlegmaria & 附生-石生 \\
\hline & & 粗䊅马尾杉 P. squarrosus & 附生-地生 \\
\hline 卷柏科 Selaginellaceae & 卷柏属 Selaginella & 䯧州卷柏 S. involvens & 附生-石生 \\
\hline 松叶蕨科 Psilotaceae & 松叶蒴属 Psilotum & 松叶蕨 P. nudum & 附生-石生 \\
\hline \multirow[t]{5}{*}{ 膜蕨科 Hymenophyllaceae } & 假脉蕨属 Crepidomanes & 长柄假脉嵚 C. racemulosum & 附生-石生 \\
\hline & 毛边菜属 Didymoglossum & 细柄单叶假脉菜 D. motleyi & 附生-石生 \\
\hline & 膜蓟属 Hymenophyllum & 蕗偋 H. badium & 附生-石生 \\
\hline & & 长柄蕗硕 H. polyanthos & 附生-石生 \\
\hline & 瓶钼属 Vandenboschia & 瓶茨 V. auriculata & 附生 \\
\hline \multirow[t]{6}{*}{ 凤尾蕨科 Pteridaceae } & 车前茨属 Antrophyum & 美叶车前蕨 A. callifolium & 附生-石生 \\
\hline & & 车前偋 A. henryi & 附生-石生 \\
\hline & & 长柄车前葓 A. obovatum & 附生-石生 \\
\hline & & 书带车前蕨 A. vittarioides & 附生 \\
\hline & 书带鄀属 Haplopteris & 唇边书带薜 H. elongata & 附生-石生 \\
\hline & & 书带偋 H. flexuosa & 附生-石生 \\
\hline \multirow[t]{12}{*}{ 铁角蕨科 Aspleniaceae } & 铁角屏属 Asplenium & 华南铁角䕋 A. austrochinense & 附生-石生 \\
\hline & & 剑叶铁角蕨 A. ensiforme & 附生-石生 \\
\hline & & 网脉铁角蒴 A. finlaysonianum & 附生-石生 \\
\hline & & 长叶铁角偋 A. prolongatum & 附生-石生 \\
\hline & & 假大羽铁角蕨 A.pseudolaserpitiifolium & 附生-石生 \\
\hline & & 厚叶铁角蕨 A. griffithianum & 附生-石生 \\
\hline & & 狭叶铁角蕨 A. scortechinii & 附生-石生 \\
\hline & & 狭翅巢蕨 A. antrophyoides & 石生-附生 \\
\hline & & 巢荻 A. nidus & 附生-石生 \\
\hline & & 长叶巢蕨 A. phyllitidis & 石生-附生 \\
\hline & & 棕鳞铁角蕨 A. yoshinagae & 附生-石生 \\
\hline & 膜叶铁角蕨属 Hymenasplenium & 切边膜叶铁角偋 H. excisum & 附生-石生 \\
\hline \multirow[t]{3}{*}{ 鳞毛蕨科 Dryopteridaceae } & 实硕属 Bolbitis & 长叶实硕 B. heteroclita & 附生-石生 \\
\hline & 舌蕨属 Elaphoglossum & 云南舌鄀 E. yunnanense & 附生 \\
\hline & 网藤嵚属 Lomagramma & 网藤蕨 L. matthewii & 附生-石生 \\
\hline 藤蕨科 Lomariopsidaceae & 藤嵚属 Lomariopsis & 藤鄀 L. cochinchinensis & 附生 \\
\hline \multirow[t]{2}{*}{ 肾硕科 Nephrolepidaceae } & 肾薑属 Nephrolepis & 肾蕨 N. cordifolia & 附生-地生 \\
\hline & & 镰叶肾蕨 N. falciformis & 附生 \\
\hline 三叉蕨科 Tectariaceae & 爬树蕨属 Arthropteris & 爬树蕨 A. palisotii & 附生-石生 \\
\hline 条蕨科 Oleandraceae & 条蕨属 Oleandra & 光叶条蕨 O. musifolia & 附生-石生 \\
\hline
\end{tabular}


吴毅, 宋亮, 刘强, 赵明旭, 卢华正, 谭运洪, 刘文耀. 西双版纳热带森林附生维管植物的物种多样性与区系特征. 生物多样性, 2016, 24（3）：271-279.

http://www. biodiversity-science. net/CN/10. 17520/biods. 2015308

\begin{tabular}{|c|c|c|c|c|}
\hline 骨碎补科 & Davalliaceae & 小膜盖蕨属 Araiostegia & 鳞轴小膜盖蕨 A. perdurans & 附生 \\
\hline & & & 美小膜盖嵚 A.pulchra & 附生-石生 \\
\hline & & 骨碎补属 Davallia & 大叶骨碎补 D. divaricata & 附生-石生 \\
\hline & & & 阔叶骨碎补 D. solida & 附生-石生 \\
\hline & & & 骨碎补 D. trichomanoides & 附生-石生 \\
\hline & & 阴石蕨属 Humata & 杯盖阴石蕨 H. griffithiana & 附生-石生 \\
\hline & & & 阴石蕨 H. repens & 附生-附生 \\
\hline & & 假钻毛蕨属 Paradavallodes & 假钻毛蕨 P. multidentata & 附生-石生 \\
\hline 水龙骨科 & Polypodiaceae & 连珠蕨属 Aglaomorpha & 崖姜 A. coronans & 附生-石生 \\
\hline & & 节肢偋属 Arthromeris & 单行节肢硕 A. wallichiana & 附生-石生 \\
\hline & & 桷嵚属 Drynaria & 团叶葪蕨 D. bonii & 附生-石生 \\
\hline & & & 小葪蒴 D. parishii & 附生-石生 \\
\hline & & & 石莲姜藓蕨 D. propinqua & 附生-石生 \\
\hline & & & 硬叶葪蕨 D. rigidula & 附生 \\
\hline & & & 槲蕨 D. roosii & 附生-石生 \\
\hline & & 棱脉莜属 Goniophlebium & 穴果棱脉蕨 G. subauriculatum & 附生 \\
\hline & & 伏石蔚属 Lemmaphyllum & 肉质伏石荻 L. carnosum & 附生-石生 \\
\hline & & & 抱石莲 L. drymoglossoides & 附生-石生 \\
\hline & & & 伏石蕨 L. microphyllum & 附生-石生 \\
\hline & & & 倒卵伏石蕨 L. microphyllum var. obovatum & 附生-石生 \\
\hline & & & 骨牌蕨 L. rostratum & 附生-石生 \\
\hline & & 鳞果星葓属 Lepidomicrosorium & 表面星蓟 L. superficiale & 附生-石生 \\
\hline & & 瓦韦属 Lepisorus & 狭叶瓦韦 L. angustus & 附生-石生 \\
\hline & & & 二色瓦韦 L. bicolor & 附生-石生 \\
\hline & & & 隐柄尖嘴䕬 L. henryi & 附生-石生 \\
\hline & & & 大瓦韦 L. macrosphaerus & 附生-石生 \\
\hline & & & 粤瓦韦 L. obscurevenulosus & 附生-石生 \\
\hline & & & 稀鳞瓦韦 L. oligolepidus & 附生-石生 \\
\hline & & & 棕鳞瓦韦 L. scolopendrium & 附生-石生 \\
\hline & & & 中华瓦韦 L. sinensis & 附生-石生 \\
\hline & & & 滇瓦韦 L. sublinearis & 附生-石生 \\
\hline & & & 瓦韦 L. thunbergianus & 附生-石生 \\
\hline & & & 阔叶瓦韦 L. tosaensis & 附生-石生 \\
\hline & & 薄唇葓属 Leptochilus & 薄唇偋 L. axillaris & 附生 \\
\hline & & & 似薄唇蕨 L. decurrens & 附生-石生 \\
\hline & & & 褐叶线蕨 L. wrightii & 附生-地生 \\
\hline & & 剑䓞属 Loxogramme & 中华剑偋 L. chinensis & 附生-石生 \\
\hline & & 星偋属 Microsorum & 羽裂星蕨 M. insigne & 石生-附生 \\
\hline & & & 膜叶星偋 M. membranaceum & 附生-石生 \\
\hline & & & 星蒴 M. punctatum & 附生-石生 \\
\hline & & 盾䓲属 Neolepisorus & 江南星蕨 N. fortunei & 附生-石生 \\
\hline & & & 显脉星蕨 N. zippelii & 附生-石生 \\
\hline & & 瘤蕨属 Phymatosorus & 光亮瘤葴 P. cuspidatus & 附生-石生 \\
\hline & & 拟水龙骨属 Polypodiastrum & 尖齿拟水龙骨 P. argutum & 附生-石生 \\
\hline
\end{tabular}


吴毅, 宋亮, 刘强, 赵明旭, 卢华正, 谭运洪, 刘文耀. 西双版纳热带森林附生维管植物的物种多样性与区系特征. 生物多样性, 2016, 24（3）：271-279.

http://www. biodiversity-science. net/CN/10. 17520/biods. 2015308

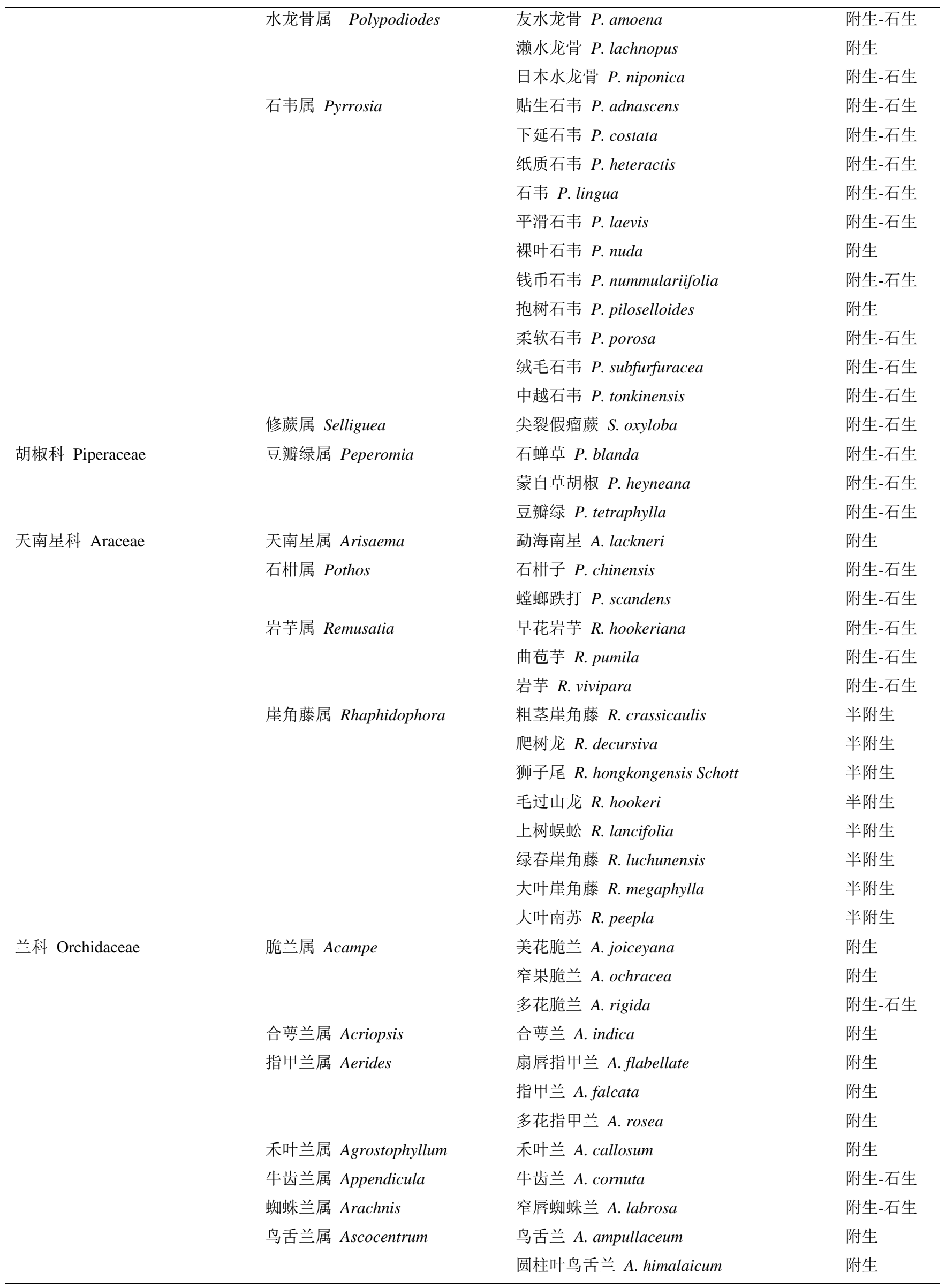


吴毅, 宋亮, 刘强, 赵明旭, 卢华正, 谭运洪, 刘文耀. 西双版纳热带森林附生维管植物的物种多样性与区系特征. 生物多样性, 2016, 24（3）：271-279.

http://www. biodiversity-science. net/CN/10. 17520/biods. 2015308

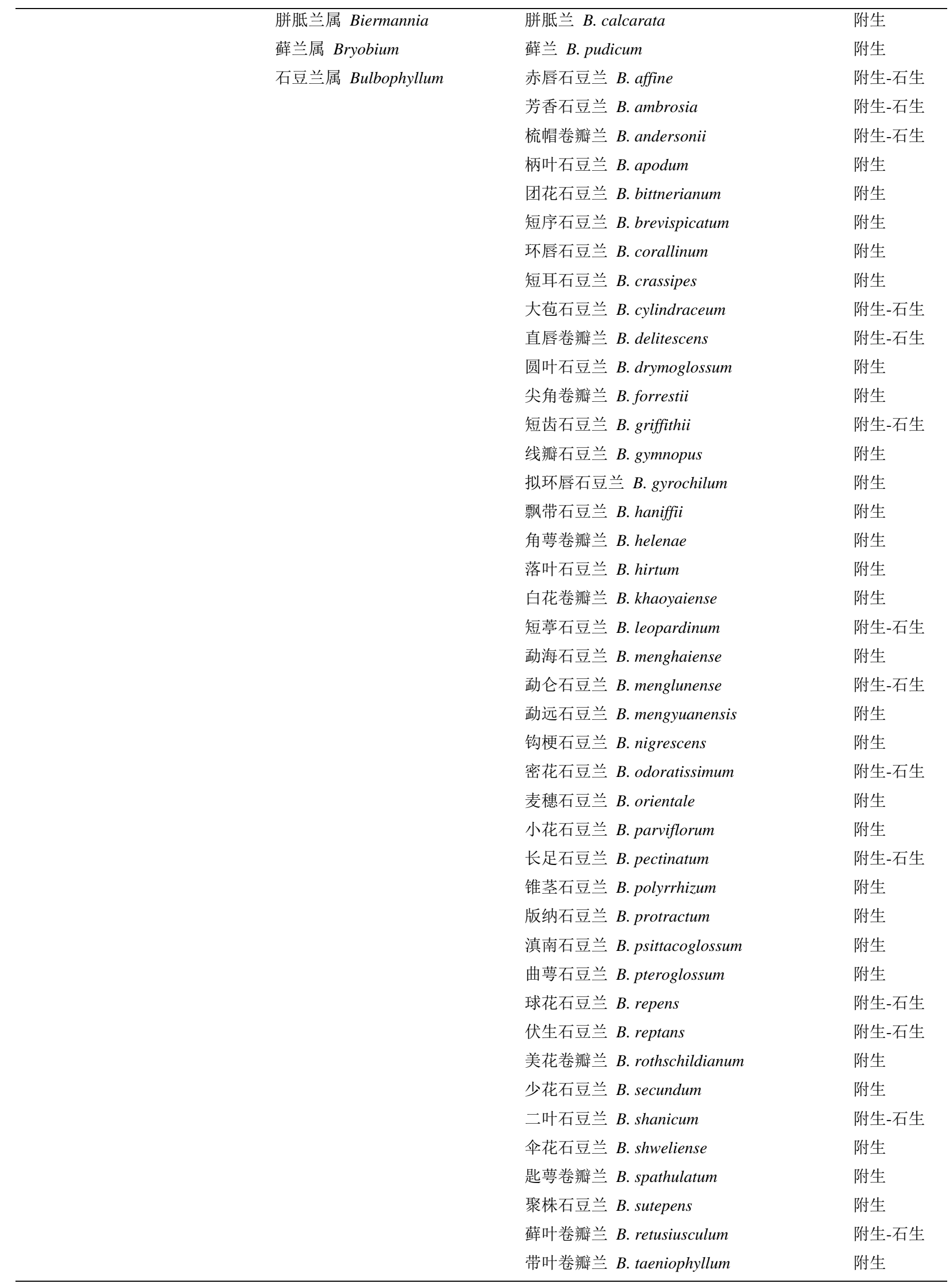


吴毅, 宋亮, 刘强, 赵明旭, 卢华正, 谭运洪, 刘文耀. 西双版纳热带森林附生维管植物的物种多样性与区系特征. 生物多样性, 2016, 24（3）：271-279.

蜂腰兰属 Bulleyia

美柱兰属 Callostylis

牛角兰属 Ceratostylis

叉柱兰属 Cheirostylis

异型兰属 Chiloschista

隔距兰属 Cleisostoma

贝母兰属 Coelogyne

蛤兰属 Conchidium

柱兰属 Cylindrolobus

兰属 Cymbidium

\begin{tabular}{|c|c|}
\hline 虎斑卷瓣兰 B. tigridum & 附生 \\
\hline 球茎石豆兰 B. triste & 附生 \\
\hline 伞花卷瓣兰 B. umbellatum & 附生 \\
\hline 直立卷瓣兰 B. unciniferum & 附生 \\
\hline 等罼卷瓣兰 B. violaceolabellum & 附生-石生 \\
\hline 双叶卷瓣兰 B. wallichii & 附生 \\
\hline 蜂腰兰 B. yunnanensis & 附生-石生 \\
\hline 竹叶美柱兰 C. bambusifolia & 附生-石生 \\
\hline 美柱兰 C. rigida & 附生 \\
\hline 叉枝牛角兰 C. himalaica & 附生-石生 \\
\hline 泰国牛角兰 C. siamensis & 附生 \\
\hline 细小叉柱兰 C.pusilla & 附生-石生 \\
\hline 白花异型兰 C. exuperei & 附生 \\
\hline 异型兰 C. yunnanensis & 附生 \\
\hline 金塔隔距兰 C. filiforme & 附生 \\
\hline 长叶隔距兰 C.fuerstenbergianum & 附生 \\
\hline 隔距兰 C.linearilobatum & 附生 \\
\hline 㐨海隔距兰 C.menghaiense & 附生 \\
\hline 南贡隔距兰 C.nangongense & 附生 \\
\hline 大序隔距兰 C.paniculatum & 附生-石生 \\
\hline 大叶隔距兰 C.racemiferum & 附生 \\
\hline 尖喙隔距兰 C.rostroatum & 附生-石生 \\
\hline C.rolfeanum & 附生 \\
\hline 毛柱隔距兰 C.simondii & 附生 \\
\hline 红花隔距兰 C.williamsonii & 附生-石生 \\
\hline 云南贝母兰 C. assamica & 附生 \\
\hline 髯毛贝母兰 C. barbata & 附生-石生 \\
\hline 流苏贝母兰 C. fimbriata & 附生-石生 \\
\hline 栗鳞贝母兰 C. flaccida & 附生-石生 \\
\hline 白花贝母兰 C. leucantha & 附生-石生 \\
\hline 长柄贝母兰 C. longipes & 附生 \\
\hline 密茎贝母兰 C. nitida & 附生 \\
\hline 长鳞贝母兰 C. ovalis & 附生-石生 \\
\hline 黄绿贝母兰 C. prolifera & 附生-石生 \\
\hline 挺茎贝母兰 C. rigida & 附生 \\
\hline 撕裂贝母兰 C. sanderae & 附生-石生 \\
\hline 疏茎贝母兰 C. suaveolens & 附生-石生 \\
\hline 三脉贝母兰 C. trinervis & 附生 \\
\hline 禾叶贝母兰 C. viscosa & 附生-石生 \\
\hline 网鞘蛤兰 C. muscicola & 附生-石生 \\
\hline 柱兰 C. marginatus & 附生 \\
\hline 纹瓣兰 C. aloifolium & 附生-石生 \\
\hline 冬凤兰 C. dayanum & 附生-石生 \\
\hline 长叶兰 C. erythraeum & 附生-石生 \\
\hline
\end{tabular}


吴毅, 宋亮, 刘强, 赵明旭, 卢华正, 谭运洪, 刘文耀. 西双版纳热带森林附生维管植物的物种多样性与区系特征. 生物多样性, 2016, 24（3）：271-279.

http://www. biodiversity-science. net/CN/10. 17520/biods. 2015308

\begin{tabular}{|c|c|c|}
\hline & 碧玉兰 C. lowianum & 附生-石生 \\
\hline & 大雪兰 C. mastersii & 附生-石生 \\
\hline & 硬叶兰 C. mannii & 附生 \\
\hline & 西藏虎头兰 C. tracyanum & 附生-石生 \\
\hline 石斛属 Dendrobium & 钩状石斛 D. aduncum & 附生 \\
\hline & 矮石斛 D. bellatulum & 附生 \\
\hline & 长苏石斛 D. brymerianum & 附生 \\
\hline & 短棒石斛 D. capillipes & 附生 \\
\hline & 翅墓石斛 D. cariniferum & 附生 \\
\hline & 束花石斛 D. chrysanthum & 附生-石生 \\
\hline & 构唇扁石斛 D. chrysocrepis & 附生-石生 \\
\hline & 鼓槌石斛 D. chrysotoxum & 附生-石生 \\
\hline & 草石斛 D. compactum & 附生 \\
\hline & 玫瑰石斛 D. crepidatum & 附生-石生 \\
\hline & 㝸唇石斛 D. cucullatum & 附生-石生 \\
\hline & 晶帽石斛 D. crystallinum & 附生 \\
\hline & 叠鞘石斛 D. denneanum & 附生 \\
\hline & 密花石斛 D. densiflorum & 附生-石生 \\
\hline & 齿瓣石斛 D. devonianum & 附生 \\
\hline & 黄花石斛 D. dixanthum & 附生 \\
\hline & 反瓣石斛 D. ellipsophyllum & 附生 \\
\hline & 景洪石斛 D. exile & 附生 \\
\hline & 串珠石斛 D. falconeri & 附生-石生 \\
\hline & 流苏石斛 D. fimbriatum & 附生-石生 \\
\hline & 棒节石斛 D. findlayanum & 附生 \\
\hline & 曲轴石斛 D. gibsonii & 附生 \\
\hline & 杯鞘石斛 D. gratiosissimum & 附生 \\
\hline & 苏瓣石斛 D. harveyanum & 附生 \\
\hline & 疏花石斛 D. henryi & 附生-石生 \\
\hline & 尖刀唇石斛 D. heterocarpum & 附生 \\
\hline & $\begin{array}{l}\text { 小黄花石斛 D. jenkinsii } \\
\text { 聚石斛 D. lindleyi }\end{array}$ & $\begin{array}{l}\text { 附生 } \\
\text { 附生 }\end{array}$ \\
\hline & 喇叭唇石斛 D. lituiflorum & 附生 \\
\hline & 美花石斛 D. loddigesii & 附生-石生 \\
\hline & 杓唇石斛 D. moschatum & 附生 \\
\hline & 石斛 D. nobile & 附生-石生 \\
\hline & 少花石斛 D. parciflorum & 附生 \\
\hline & 肿节石斛 D. pendulum & 附生 \\
\hline & 单葶草石斛 D. porphyrochilum & 附生-石生 \\
\hline & 报春石斛 D. polyanthum & 附生 \\
\hline & 针叶石斛 D. pseudotenellum & 附生 \\
\hline & 竹枝石斛 D. salaccense & 附生-石生 \\
\hline & 㭞海石斛 D. sinominutiflorum & 附生 \\
\hline & 剑叶石斛 D. spatella & 附生-石生 \\
\hline
\end{tabular}


吴毅, 宋亮, 刘强, 赵明旭, 卢华正, 谭运洪, 刘文耀. 西双版纳热带森林附生维管植物的物种多样性与区系特征. 生物多样性, 2016, 24（3）：271-279.

\begin{tabular}{|c|c|c|}
\hline & 梳唇石斛 D. strongylanthum & 附生 \\
\hline & 叉唇石斛 D. stuposum & 附生 \\
\hline & 具槽石斛 D. sulcatum & 附生-石生 \\
\hline & 刀叶石斛 D. terminale & 附生-石生 \\
\hline & 球花石斛 D. thyrsiflorum & 附生 \\
\hline & 紫苑石斛 D. transparens & 附生 \\
\hline & 翅梗石斛 D. trigonopus & 附生 \\
\hline & 大苞鞘石斛 D. wardianum & 附生 \\
\hline & 高山石斛 D. wattii & 附生 \\
\hline \multirow[t]{3}{*}{ 线兰属 Dendrolirium } & 绿花绒兰 D. lanigerum & 附生-石生 \\
\hline & 白绵线兰 D. lasiopetalum & 附生-石生 \\
\hline & 线兰 D. tomentosum & 附生-石生 \\
\hline 舌兰属 Diploprora & 蛇舌兰 D. championii & 附生-石生 \\
\hline 栖林兰属 Drymoda & 栖林兰 D. siamensis & 附生 \\
\hline \multirow[t]{2}{*}{ 厚唇兰属 Epigeneium } & 宽叶厚唇兰 E. amplum & 附生-石生 \\
\hline & 景东厚唇兰 E. fuscescens & 附生-石生 \\
\hline \multirow[t]{6}{*}{ 毛兰属 Eria } & 匍茎毛兰 E. clausa & 附生-石生 \\
\hline & 半柱毛兰 E. corneri & 附生-石生 \\
\hline & 足茎毛兰 E. coronaria & 附生-石生 \\
\hline & 香花毛兰 E. javanica & 附生-石生 \\
\hline & 浮萍毛兰 E. spirodela & 附生 \\
\hline & 砚山毛兰 E. yanshanensis & 附生 \\
\hline 毛梗兰属 Eriodes & 毛梗兰 E. barbata & 附生 \\
\hline 花蜘蛛兰属 Esmeralda & 口盖花蜘蛛兰 E. bella & 附生 \\
\hline \multirow[t]{5}{*}{ 金石斛属 Flickingeria } & 滇金石斛 F. albopurpurea & 附生-石生 \\
\hline & 二色金石斛 F. bicolor & 附生-石生 \\
\hline & 红头金石斛 F. calocephala & 附生-石生 \\
\hline & 同色金石斛 F. concolor & 附生 \\
\hline & 三脊金石斛 F. tricarinata & 附生 \\
\hline \multirow[t]{6}{*}{ 盆距兰属 Gastrochilus } & 大花盆距兰 G. bellinus & 附生 \\
\hline & 盆距兰 G. calceolaris & 附生 \\
\hline & 无茎盆距兰 G. obliquus & 附生-石生 \\
\hline & 滇南盆距兰 G. platycalcaratus & 附生 \\
\hline & 小唇盆距兰 G. pseudodistichus & 附生 \\
\hline & 云南盆距兰 G. yunnanensis & 附生 \\
\hline \multirow[t]{2}{*}{ 槽舌兰属 Holcoglossum } & 大根槽舌兰 H. amesianum & 附生 \\
\hline & 管叶槽舌兰 H. kimballianum & 附生-石生 \\
\hline 湿唇兰属 Hygrochilus & 湿唇兰 H. parishii & 附生-石生 \\
\hline 袋距兰属 Lesliea & 袋距兰 L. mirabilis & 附生 \\
\hline \multirow[t]{5}{*}{ 羊耳蒜属 Liparis } & 扁茎羊耳赫 L. assamica & 附生 \\
\hline & 镰翅羊耳蒜 L. bootanensis & 附生-石生 \\
\hline & 丛生羊耳蒜 L. cespitosa & 附生-石生 \\
\hline & 小巧羊耳蒜 L. delicatula & 附生 \\
\hline & 大花羊耳赫 L. distans & 附生-石生 \\
\hline
\end{tabular}


吴毅, 宋亮, 刘强, 赵明旭, 卢华正, 谭运洪, 刘文耀. 西双版纳热带森林附生维管植物的物种多样性与区系特征. 生物多样性, 2016, 24（3）：271-279.

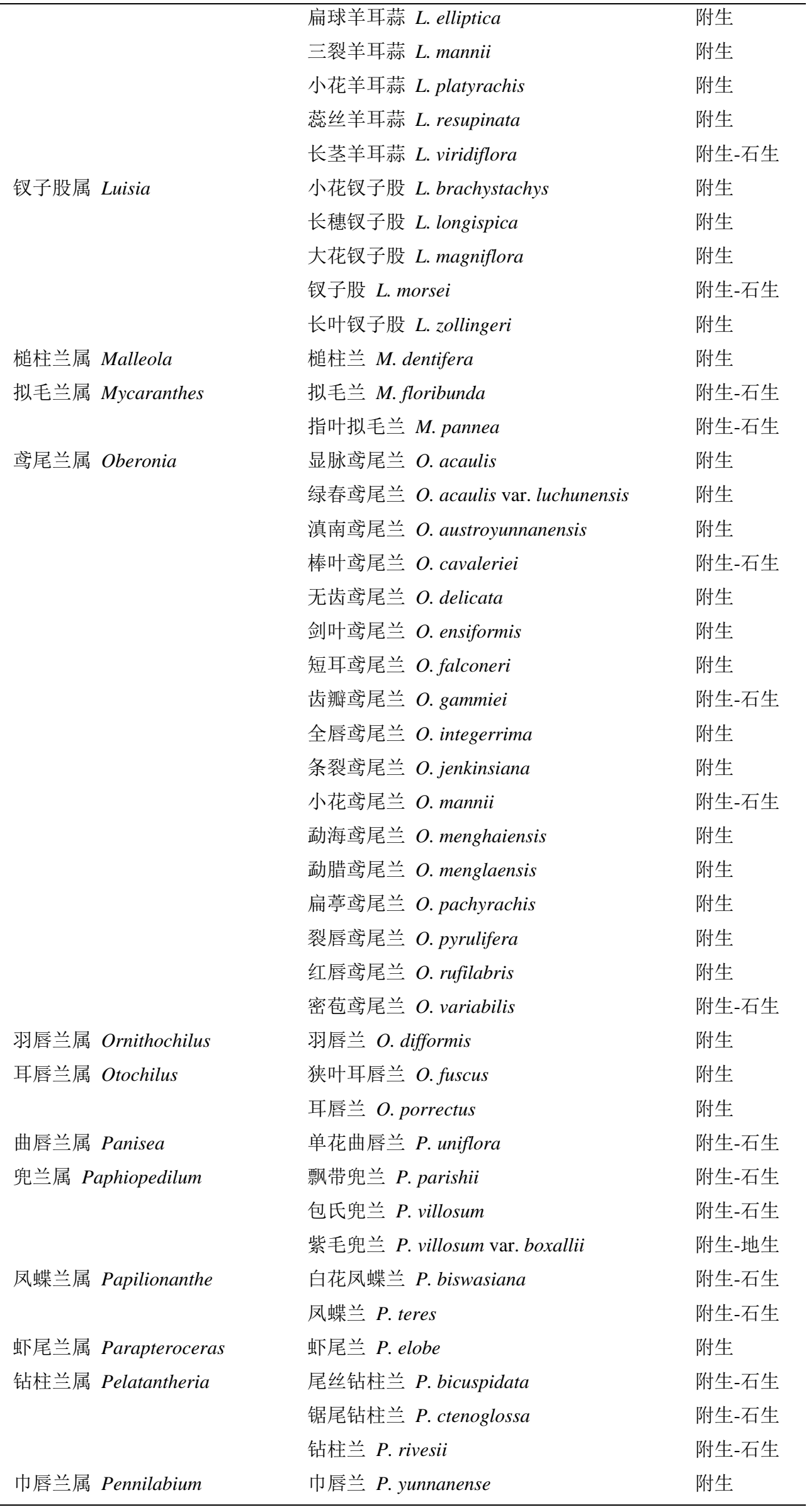


吴毅, 宋亮, 刘强, 赵明旭, 卢华正, 谭运洪, 刘文耀. 西双版纳热带森林附生维管植物的物种多样性与区系特征. 生物多样性, 2016, 24（3）：271-279.

http://www. biodiversity-science. net/CN/10. 17520/biods. 2015308

\begin{tabular}{|c|c|c|}
\hline 蝴蝶兰属 Phalaenopsis & 尖囊蝴蝶兰 P. braceana & 附生 \\
\hline & 囊唇蝴蝶兰 P. gibbosa & 附生 \\
\hline & 版纳蝴蝶兰 P. mannii & 附生 \\
\hline & 小尖囊蝴蝶兰 P. taenialis & 附生 \\
\hline 石仙桃属 Pholidota & 节茎石仙桃 P. articulata & 附生-石生 \\
\hline & 石仙桃 P. chinensis & 附生-石生 \\
\hline & 宿苞石仙桃 P. imbricata & 附生-石生 \\
\hline & 粗脉石仙桃 P. pallida & 附生 \\
\hline & 凹唇石仙桃 P. convallariae & 附生 \\
\hline & 中文名待定 P. recurva & 附生 \\
\hline 馥兰属 Phreatia & 馥兰 P. formosana & 附生 \\
\hline 苹兰属 Pinalia & 钝叶苹兰 P. acervata & 附生 \\
\hline & 粗茎苹兰 P. amica & 附生 \\
\hline & 双点苹兰 P. bipunctata & 附生 \\
\hline & 长苞苹兰 P. obvia & 附生-石生 \\
\hline & 厚叶苹兰 P. pachyphylla & 附生-石生 \\
\hline & 密花苹兰 P. spicata & 附生-石生 \\
\hline & 鹅白苹兰 P. stricta & 附生-石生 \\
\hline & 马齿苹兰 P. szetchuanica & 附生 \\
\hline & 滇南苹兰 P. yunnanensis & 附生 \\
\hline 独蒜兰属 Pleione & 病鞘独蒜兰 P. praecox & 附生-石生 \\
\hline 柄唇兰属 Podochilus & 柄唇兰 P. khasianus & 附生 \\
\hline 多穗兰属 Polystachya & 多穗兰 P. concreta & 附生 \\
\hline 鹿角兰属 Pomatocalpa & 台湾鹿角兰 P. undulatum & 附生 \\
\hline 盾柄兰属 Porpax & 盾柄兰 P. ustulata & 附生-石生 \\
\hline 长足兰属 Pteroceras & 长足兰 P. leopardinum & 附生 \\
\hline 钻喙兰属 Rhynchostylis & 钻嗀兰 $R$. retusa & 附生 \\
\hline 寄树兰属 Robiquetia & 寄树兰 R. succisa & 附生-石生 \\
\hline 大喙兰属 Sarcoglyphis & 短帽大喙兰 S. magnirostris & 附生 \\
\hline & 大嗀兰 S. smithianus & 附生-石生 \\
\hline 匙唇兰属 Schoenorchis & 匙唇兰 S. gemmate & 附生 \\
\hline & 圆叶匙唇兰 S. tixieri & 附生 \\
\hline 掌唇兰属 Staurochilus & 掌唇兰 S. dawsonianus & 附生 \\
\hline & 小掌唇兰 S. loratus & 附生 \\
\hline 大苞兰属 Sunipia & 黄花大苞兰 S. andersonii & 附生-石生 \\
\hline & 绿花大苞兰 S. annamensis & 附生 \\
\hline & 二色大苞兰 S. bicolor & 附生-石生 \\
\hline & 白花大苞兰 S. candida & 附生 \\
\hline & 大花大苞兰 S. grandiflora & 附生 \\
\hline & 淡黑大苞兰 S. nigricans & 附生 \\
\hline & 大苞兰 S. scariosa & 附生-石生 \\
\hline & 光花大苞兰 S. thailandica & 附生 \\
\hline 带叶兰属 Taeniophyllum & 带叶兰 T. glandulosum & 附生 \\
\hline & 兒唇带叶兰 T.pusillum & 附生 \\
\hline
\end{tabular}


吴毅, 宋亮, 刘强, 赵明旭, 卢华正, 谭运洪, 刘文耀. 西双版纳热带森林附生维管植物的物种多样性与区系特征. 生物多样性, 2016, 24（3）：271-279.

http://www. biodiversity-science. net/CN/10. 17520/biods. 2015308

\begin{tabular}{|c|c|c|c|}
\hline & 矮柱兰属 Thelasis & 矮柱兰 T. pygmaea & 附生-石生 \\
\hline & 白点兰属 Thrixspermum & 白点兰 $T$. centipeda & 附生 \\
\hline & & 同色白点兰 T. trichoglottis & 附生 \\
\hline & & 吉氏白点兰 $T . t s i i$ & 附生-石生 \\
\hline & 毛舌兰属 Trichoglottis & 毛舌兰 T. triflora & 附生 \\
\hline & 毛鞘兰属 Trichotosia & 瓜子毛鞘兰 T. dasyphylla & 附生 \\
\hline & & 小叶毛鞘兰 T. microphylla & 附生 \\
\hline & & 高茎毛鞘兰 T. pulvinata & 附生-石生 \\
\hline & 叉喙兰属 Uncifera & 叉喙兰 U. acuminate & 附生 \\
\hline & 万代兰属 Vanda & 白柱万代兰 V. brunnea & 附生 \\
\hline & & 大花万代兰 V. coerulea & 附生 \\
\hline & & 小蓝万代兰 V. coerulescens & 附生 \\
\hline & & 琴唇万带兰 V. concolor & 附生-石生 \\
\hline & & 叉唇万代兰 $V$. cristata & 附生 \\
\hline & & 矮万代兰 V.pumila & 附生 \\
\hline & 拟万代兰属 Vandopsis & 拟万代兰 V. gigantea & 附生 \\
\hline & & 白花拟万代兰 $V$. undulata & 附生-石生 \\
\hline 姜科 Zingiberaceae & 距药姜属 Cautleya & 距药姜 C. gracilis & 附生-地生 \\
\hline & 姜花属 Hedychium & 毛姜花 H. villosum & 附生-石生 \\
\hline & 喙花姜属 Rhynchanthus & 喙花姜 $R$. beesianus & 附生-地生 \\
\hline 景天科 Crassulaceae & 石莲属 Sinocrassula & $\begin{array}{l}\text { 褐斑石莲 S. luteorubra var. maculosa H. } \\
\text { Chuang }\end{array}$ & 附生-石生 \\
\hline 桑科 Moraceae & 榕属 Ficus & 高山榕 F. altissima & 半附生 \\
\hline & & 环纹榕 F. annulata & 半附生 \\
\hline & & 垂叶榕 F. benjamina var. benjamina & 半附生 \\
\hline & & 从毛垂叶榕 F. benjamina var. nuda & 半附生 \\
\hline & & 雅榕 F. concinna var. concinna & 半附生 \\
\hline & & 近无柄雅榕 F. concinna var. subsessilis & 半附生 \\
\hline & & 钝叶榕 F. curtipes & 半附生 \\
\hline & & 歪叶榕 F. cyrtophylla & 半附生 \\
\hline & & 曲枝榕 F. geniculata & 半附生 \\
\hline & & 大青树 F. hookeriana & 半附生 \\
\hline & & 滇缅榕 F. kurzii & 半附生 \\
\hline & & 光叶榕 F. laevis & 半附生 \\
\hline & & 青藤公 F. langkokensis & 半附生 \\
\hline & & 榕树 F. microcarpa & 半附生 \\
\hline & & 豆果榕 F. pisocarpa & 半附生 \\
\hline & & 羊乳榕 F. sagittata & 半附生 \\
\hline & & 尾尖爬藤榕 F. sarmentosa var. lacrymans & 半附生 \\
\hline & & 劲直榕 F. stricta & 半附生 \\
\hline & & 笔管榕 F. superba var. japonica & 半附生 \\
\hline & & 斜叶榕 F. tinctoria subsp. gibbosa & 半附生 \\
\hline & & 黄葛树 F. virens & 半附生 \\
\hline 菖麻科 Urticaceae & 楼梯草属 Elatostema & 迭叶楼梯草 E. salvinioides & 附生-石生 \\
\hline & 藤麻属 Procris & 藤麻 P. crenata & 附生-石生 \\
\hline
\end{tabular}


吴毅, 宋亮, 刘强, 赵明旭, 卢华正, 谭运洪, 刘文耀. 西双版纳热带森林附生维管植物的物种多样性与区系特征. 生物多样性, 2016, 24（3）：271-279.

http://www. biodiversity-science. net/CN/10. 17520/biods. 2015308

\begin{tabular}{|c|c|c|c|}
\hline 野牡丹科 Melastomataceae & 酸脚杆属 Medinilla & 雉序酸角杆 M. himalayana & 附生 \\
\hline \multirow[t]{9}{*}{ 杜鹃花科 Ericaceae } & \multirow[t]{6}{*}{ 树萝卜属 Agapetes } & 环募树萝卜 A. brandisiana & 附生 \\
\hline & & 缅甸树萝卜 A. burmanica & 附生 \\
\hline & & 沧源树萝卜 A. inopinata & 附生 \\
\hline & & 灯笼花 A. lacei & 附生 \\
\hline & & 深裂树萝卜 A. lobbii & 附生-石生 \\
\hline & & 白花树萝卜 A. mannii & 附生-石生 \\
\hline & 杜鹃花属 Rhododendron & 宝兴杜鹃 R. moupinense & 附生-石生 \\
\hline & \multirow[t]{2}{*}{ 越桔属 Vaccinium } & 苍山越桔 V. delavayi & 附生-地生 \\
\hline & & 岩生越桔 V. scopulorum & 附生-石生 \\
\hline 茜草科 Rubiaceae & 石丁香属 Neohymenopogon & 石丁香 N. parasiticus & 附生-石生 \\
\hline 马钱科 Loganiaceae & 灰莉属 Fagraea & 灰莉 F. ceilanica & 兼性附生 \\
\hline \multirow[t]{16}{*}{ 萝藦科 Asclepiadaceae } & \multirow[t]{5}{*}{ 眼树莲属 Dischidia } & 线叶眼树莲 D. singularis & 附生 \\
\hline & & 倒卵叶眼树莲 D. griffithii & 附生 \\
\hline & & 眼树莲 D. chinensis & 附生 \\
\hline & & 圆叶眼树莲 D. nummularia & 附生 \\
\hline & & 滴锡眼树莲 D. tonkinensis & 附生-石生 \\
\hline & \multirow[t]{10}{*}{ 球兰属 Hoya } & 球兰 H. carnosa & 附生 \\
\hline & & 景洪球兰 H. chinghungensis & 附生 \\
\hline & & 护耳草 $H$. fungii & 附生 \\
\hline & & 黄花球兰 $H . f u s c a$ & 附生-石生 \\
\hline & & 线叶球兰 H. linearis & 附生 \\
\hline & & 凸脉球兰 H. nervosa & 附生 \\
\hline & & 琴叶球兰 H. pandurata & 附生 \\
\hline & & 三脉球兰 H.pottsii & 附生-石生 \\
\hline & & 毛球兰 H. villosa & 附生 \\
\hline & & 蜂出巢 H. multiflora & 附生 \\
\hline & 扇叶藤属 Micholitzia & 扇叶藤 M. obcordata & 附生-石生 \\
\hline \multirow[t]{16}{*}{ 苦菅苔科 Gesneriaceae } & \multirow[t]{15}{*}{ 芒毛苣苔属 Aeschynanthus } & 长尖芒毛苣苔 A. acuminatissimus & 附生 \\
\hline & & 芒毛苣苔 A. acuminatus & 附生-石生 \\
\hline & & 轮叶芒毛菅苔 A. andersonii & 附生 \\
\hline & & 狭矩芒毛苣苔 A. angustioblongus & 附生 \\
\hline & & 滇南芒毛菅苔 A. austroyunnanensis & 附生-石生 \\
\hline & & 显苞芒毛菅苔 A. bracteatus & 附生-石生 \\
\hline & & 小齿芒毛菅苔 A. chiritoides & 附生 \\
\hline & & 细芒毛苣苔 A. gracilis & 附生 \\
\hline & & 束花芒毛苣苔 A. hookeri & 附生 \\
\hline & & 矮芒毛苣苔 A. humilis & 附生 \\
\hline & & 长茎芒毛苣苔 A. longicaulis & 附生 \\
\hline & & 预醒芒毛苣苔 A. mengxingensis & 附生 \\
\hline & & 大花芒毛苣苔 A. mimetes & 附生 \\
\hline & & 扁柄芒毛苣苔 A. planipetiolatus & 附生 \\
\hline & & 华丽芒毛苣苔 A. superbus & 附生-石生 \\
\hline & 紫花菅苔属 Loxostigma & 紫花苍苔 L. griffithii & 附生-石生 \\
\hline
\end{tabular}


吴毅, 宋亮, 刘强, 赵明旭, 卢华正, 谭运洪, 刘文耀. 西双版纳热带森林附生维管植物的物种多样性与区系特征. 生物多样性, 2016, 24（3）：271-279.

http://www. biodiversity-science. net/CN/10. 17520/biods. 2015308

\begin{tabular}{|c|c|c|c|}
\hline & & 澜沧紫花苣苔 L. mekongense & 附生-石生 \\
\hline & 吊石苣苔属 Lysionotus & 桂黔吊石苣苔 L. aeschynanthoides & 附生-石生 \\
\hline & & 齿叶吊石苣苔 L. serratus & 附生-石生 \\
\hline 玄参科 Scrophulariaceae & 美丽桐属 Wightia & 美丽桐 W. speciosissima & 半附生 \\
\hline 狸藻科 Lentibulariaceae & 狸藻属 Utricularia & 圆叶挖耳草 U. striatula & 附生-石生 \\
\hline \multirow[t]{3}{*}{ 五加科 Araliaceae } & 鹅掌柴属 Schefflera & 密脉鹅掌柴 S. elliptica & 附生-地生 \\
\hline & & 白花鹅掌柴 S. leucantha & 附生-地生 \\
\hline & & 球序鹅掌柴 S. pauciflora & 附生-地生 \\
\hline
\end{tabular}

